\title{
Evaluation Of Dead Space In Post Endodontically Treated Cast Post Cases - A Retrospective Study
}

Research Article

Aishuwariya $\mathrm{T}^{1}$, Deepak $\mathrm{S}^{2}$, Delphin Priscilla Antony $\mathrm{S}^{3}$

${ }^{1}$ Department of Conservative Dentistry and Endodontics, Saveetha Dental College and Hospital, Saveetha Institute of Medical and Technical Science, Saveetha University, India.

${ }^{2}$ Senior Lecturer, Department of Conservative Dentistry and Endodontics, Saveetha Dental College and Hospital, Saveetha Institute Of Medical and Technical Science, Saveetha University, India.

${ }^{3}$ Senior Lecturer, Department of Conservative Dentistry and Endodontics, Saveetha Dental College and Hospital, Saveetha Institute Of Medical and Technical Science, Saveetha University, India.

\section{Abstract}

The success of endodontic treatment is 53-96\%, Depends on various factors like tooth type, preoperative apical status, method of obturation, irrigation, coronal seal permanent restoration.

Grossly decayed endodontically treated teeth are often restored with post and core. Apical microleakage can lead to failure of the endodontic therapy.So the aim of this study was to measure the distance between post and residual guttapercha in cast post cases. Dental records and radiographs of patients treated with cast post cases were obtained from DIAS (From June 2019- March 2020) examined by the same examiner. Patients were categorized into three groups based on the distance between the remaining obturation material and post. A total of 70 cases were examined. Out of which $21 \%$ of cases belonged to Group I and $68 \%$ of the cases were categorized into Group II. Within the limitation of the study, most of the cases had an average dead space of 0.1-2 $\mathrm{mm}(68 \%)$. Within the limitation of the study, most of the cases had an average dead space of $0.1-2 \mathrm{~mm}(68 \%)$. The dead space occurring after a post restoration can be a good shelter for the microorganisms. So, radiographic confirmation of the post adaptation should be performed before cementation of all kinds of posts.

Keywords: Cast Post; Dead Space; Endodontic Therapy.

\section{Introduction}

The success of an endodontic treatment is 53\%-96\% [33, 7]. It depends on many factors like tooth type, preoperative operator skills and quality of coronal seal. The longevity of endodontically treated teeth has been greatly enhanced by continuing advancements made in endodontic therapy and restorative procedures $[5$, $16,21,28]$.

Endodontically treated teeth are often broken teeth which requires restoration with endodontic post. The main purpose of post is to retain the permanent restoration and disperse the factors along the long axis of the tooth to the periodontium [29, 8].

However the seal provided by a complete full length of obturation gets compromised after post space preparation. Coronal microleakage into the root canal by bacteria can lead to failure of endodontic therapy $[5,16,20,28]$. So, immediate and proper coronal restoration is very important $[6,12]$.

Apical leakage is one of the most important factors in the outcome of endodontic traenmentr and is positively correlated with technical quality of the root canal filling $[10,26]$.

Recent epidemiologic studies that evaluated the success rate of root filled teeth have stated that the leakage from the oral environment along the root canal filling to the periapical region was also a contributing factor $[32,27]$. The significance of coronal restoration on periradicular heath was also supported by ex vivo study $[35,38]$.

A custom made cast post can either be cast from a direct pattern or an indirect pattern. In case of the direct technique, the pattern

*Corresponding Author:

Deepak S,

Senior Lecturer, Department of Conservative Dentistry and Endodontics, Saveetha Dental College and Hospital, Saveetha Institute Of Medical and Technical Science, Saveetha University, India.

E-mail: deepaks.sdc@saveetha.com

Received: November 10, 2020

Accepted: November 21, 2020

Published: November 30, 2020

Citation: Aishuwariya T, Deepak S, Delphin Priscilla Antony S. Evaluation Of Dead Space In Post Endodontically Treated Cast Post Cases - A Retrospective Study. Int J Dentistry Oral Sci. 2020;S10:02:0024:131-134. doi: http://dx.doi.org/10.19070/2377-8075-SI02-0100024

Copyright: Deepak $\mathbf{S}^{\circ}$ 2020. This is an open-access article distributed under the terms of the Creative Commons Attribution License, which permits unrestricted use, distribution and reproduction in any medium, provided the original author and source are credited. 
can either be made using inlay wax or it can be made using pattern resin. In case of conventional indirect technique, an elastomeric impression material along with some kind of reinforcement is used [3]. So the aim of the study was to evaluate the dead space in postendodotically treated cast post cases.

\section{Materials And Methods}

This retrospective study was carried out at Department Of Conservative Dentistry And Endodontic, Saveetha dental college and hospitals, Chennai.

As this study was entirely based on data collection from existing dental records available in DIAS (Dental Information Archiving Software) Saveetha Dental College, ethical clearance was not obtained.

Dental record of the patients who had undergone treatment for the management of badly broken down teeth with cast post from June 2019 to March 2020 were retrospectively examined by single examiner.

Only the patient who had got their treatment done by the same clinician and full dental records were included for the study. Data were collected from 70 patient records. Following data were collected from each patient - Age, Gender, Type of teeth and the radiographs of each were evaluated for the dead space (Distance between obturating material and the post), and were broadly divided into three categories based on this into Group I,II and III.

I-No gap- $0 \mathrm{~mm}$

II-less than $2 \mathrm{~mm}$

III-more than $2 \mathrm{~mm}$ [Table 1]

Data were tabulated in excel sheets and statistical analysis was done using SPSS 21.0 version.

Descriptive analysis of the data obtained was done and Chi square test was done to check the association between Age, Gender and Number of cases.

\section{Results And Discussion}

A total of 70 cases were examined. $21 \%$ of cases were grouped into group I, 68\% were categorised under group II and 1\% of cases were grouped under Group III.

On the whole, most of the cases belonged to the 21-30 age group-57\%. Minimum number of cases were reported in $61-70$ age group- $13 \%$.

Maximum number of cases were reported in Male- $62 \%$, Minimum number of cases were reported in Female-37\%. When the association between the age groups and the teeth was checked, it was found to be not significant with $\mathrm{P}$ value more than 0.05 .

This is a retrospective study based on the evaluation of radiographs. A major drawback of this type of analysis is the impossibility of deciding whether aperiapicalpathosis is healing or not because of its gives only static description of the dynamic inflammatory process $[13,17,36,31,14]$.

This study is based on evaluation of periapical radiographs. There have been doubts about the sensitivity of the periapical radiographs in terms of detection of periapical status evaluation. However, Mohammed et al showed no significant difference between panoramic and periapical radiographs. This finding was also supported by Ahlquest et al [2, 24].

Endodontically treated teeth most commonly receive post retained restoration $[34,19,30]$. Recently, more studies have been focussed on the coronal leakage of the post restoration. Results showed that not only the length of remaining root canal filling but also the adhesion between the post and root canal dentin played a key role in coronal microleakage.

It has been mentioned that the seal of the post and core had to be improved for the prevention of recontamination [1, 22, 25]. Fogel et al showed that none of the stainless steel based post systems were capable of achieving a fluid tight seal regardless of the luting material [9]. Moreover, poor cementation of temporary crown or temporary post is also an important factor in coronal leakage.

The gap between the post and the remaining root canal filling is another decisive factor in the invasion of microorganisms after post restoration. Nevertheless, there are few studies about the effect of this gap in the success of the endodontically treated teeth. It is obvious that the root canals should be hermetically obturated for the topmost outcomes $[18,20,36]$.

Table 1. Criteria for the dead space evaluation.

\begin{tabular}{|c|c|}
\hline GROUPS & $\begin{array}{c}\text { CRITERIA FOR DEAD } \\
\text { SPACE EVALUATION }\end{array}$ \\
\hline I & $0 \mathrm{~mm}$ \\
\hline II & Less than $2 \mathrm{~mm}$ \\
\hline III & More than $2 \mathrm{~mm}$ \\
\hline
\end{tabular}

Table 2. Number of Cases in each Group.

\begin{tabular}{|c|c|}
\hline GROUPS & NUMBER OF TEETH \\
\hline I & 15 \\
\hline II & 48 \\
\hline III & 7 \\
\hline
\end{tabular}


Figure 1. This bar chart represents the dead space in cast post cases. $x$-axis represents the group and y-axis represents the total number of teeth. Most of the teeth had group 2 which is dead space of less than $2 \mathrm{~mm}$.

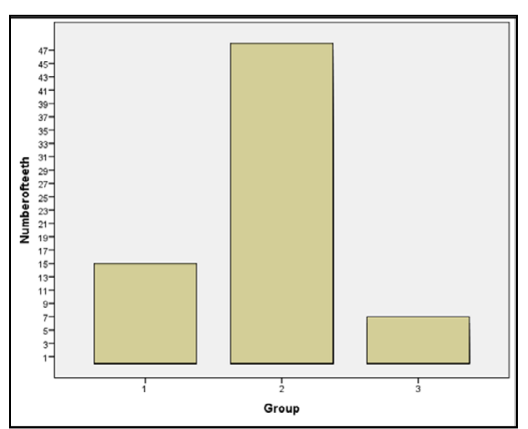

Figure 2. Bar graph represents the distribution of cast post cases with relation to tooth number. $\mathrm{X}$-axis represents the groups and the $y$-axis gives the total number of teeth. The most common teeth seen in all the three groups was 11 (maxillary central incisors).

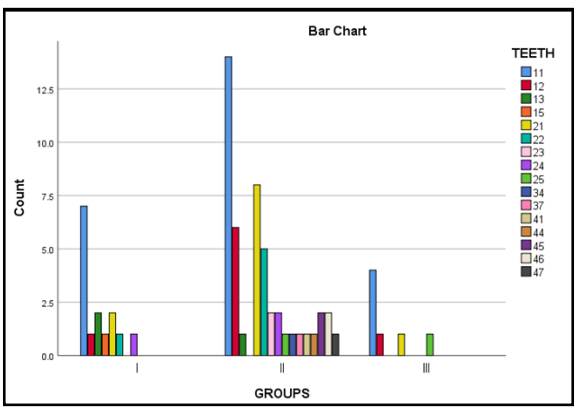

Figure 3. This bar graph represents the distribution of cast post cases in all three groups . X-axis gives the teeth number and $\mathrm{y}$-axis gives the count of teeth, The most common teeth seen is 11 among all three groups.

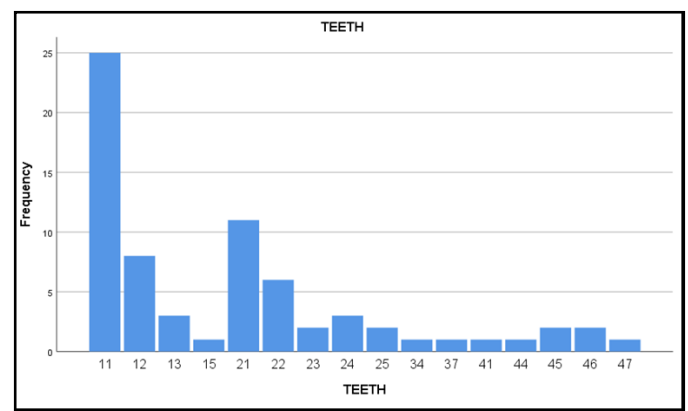

Figure 4. Bar graph represents the association between groups and count of teeth. $\mathrm{X}$ Axis represents the groups and $\mathrm{Y}$ axis represents the count of teeth in each group. Chi square test was done and association was found to be statistically not significant. Pearson's Chi square value:8.598, Df:10, p value:0.571 (>0.05).

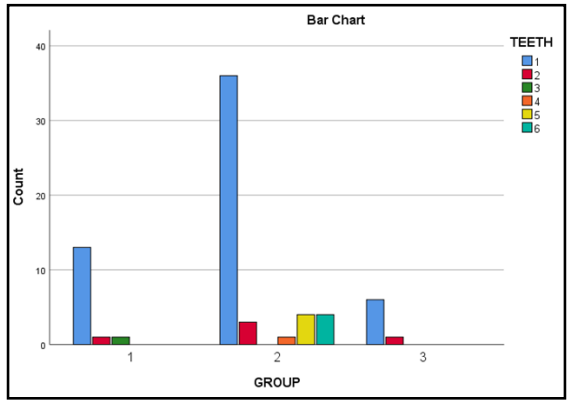

McAndrew et al, mentioned in his study that the gap between the post and the obturating material could be a contributing factor in the prognosis of endodontically treated teeth $[11,15]$.

Because one of the primary functions of the root canal filling is entombing the bacteria in the dentinal tubules. However the space between the post and the obturating material (Dead space) can be a good shelter for the microorganisms that negatively affect the outcome of the endodontic therapy.

A custom made cast post can be fabricated by direct or indirect technique. The main disadvantage of this technique is that if the selected reinforcement, i.e., the wire or plastic post is too tight, then the impression material strips away from it when the impression is removed. Furthermore, placing the reinforcement into the canal is an additional time-consuming procedure. In addition, seating the reinforcement onto the orifices of the root canals may 
be difficult or impractical in cases with difficult clinical access or in cases where multiple teeth are involved $[3,4]$.

In teeth with cast post, the explanation of this gap may be inaccurate impression of post space or thermal contraction of metal alloys during casting procedure. Therefore radiographic confirmation of post adaptation should be performed before cementation of all kinds of posts $[23,39]$.

\section{Conclusion}

Within the limitation of the study, most of the cases had an average dead space of $0.1-2 \mathrm{~mm}(68 \%)$. The dead space can be a good shelter for the microorganisms. So, radiographic confirmation of the post adaptation should be performed before cementation of all kinds of posts.

\section{References}

[1]. Abramovitz L, Lev R, Fuss Z, Metzger Z. The unpredictability of seal after post space preparation: a fluid transport study. J Endod. 2001 Apr;27(4):2925. PubmedPMID: 11485271.

[2]. Ahlqwist M, Halling A, Hollender L. Rotational panoramic radiography in epidemiological studies of dental health. Comparison between panoramic radiographs and intraoral full mouth surveys. Swed Dent J. 1986;10(12):73-84. PubmedPMID: 3518113.

[3]. Al-Dhalaan, R. (no date) 'Prosthodontic management of endodontically treated teeth; factors determining post selection, foundation restorations and review of success failure data', Back to cited text, (2).

[4]. Al-Rashed AA, Al-Rashed MA. Modified procedure of indirect pattern for fabricating cast post and core. Pakistan Oral \& Dental Journal. 2015 Dec $1 ; 35(4)$.

[5]. Alves J, Walton R, Drake D. Coronal leakage: endotoxin penetration from mixed bacterial communities through obturated, post-prepared root canals. J Endod. 1998 Sep;24(9):587-91. PubmedPMID: 9922745.

[6]. Cabrera P, Vera J, White R, Goldman M, Karapanou V. RS 10 The effect of immediate and delayed post space preparation on apical dye leakage. Journal of Endodontics. 1994 Apr 1;20(4):190.

[7]. Farzaneh M, Abitbol S, Friedman S. Treatment outcome in endodontics: the Toronto study. Phases I and II: Orthograde retreatment. J Endod. 2004 Sep;30(9):627-33. PubmedPMID: 15329565.

[8]. Fernandes AS, Dessai GS. Factors affecting the fracture resistance of post-core reconstructed teeth: a review. Int J Prosthodont. 2001 Jul-Aug;14(4):355-63. PubmedPMID: 11508092.

[9]. Fogel HM. Microleakage of posts used to restore endodontically treated teeth. J Endod. 1995 Jul;21(7):376-9. PubmedPMID: 7499979.

[10]. Gomes AC, Nejaim Y, Silva AI, Haiter-Neto F, Cohenca N, Zaia AA, et al. Influence of Endodontic Treatment and Coronal Restoration on Status of Periapical Tissues: A Cone-beam Computed Tomographic Study. J Endod. 2015 Oct;41(10):1614-8. PubmedPMID: 26307508.

[11]. Grieve AR, McAndrew R. A radiographic study of post-retained crowns in patients attending a dental hospital. Br Dent J. 1993 Mar 20;174(6):197201. PubmedPMID: 8448059.

[12]. Heling I, Gorfil C, Slutzky H, Kopolovic K, Zalkind M, Slutzky-Goldberg I. Endodontic failure caused by inadequate restorative procedures: review and treatment recommendations. J Prosthet Dent. 2002 Jun;87(6):674-8. PubmedPMID: 12131891

[13]. Hommez GM, Coppens CR, De Moor RJ. Periapical health related to the quality of coronal restorations and root fillings. IntEndod J. 2002 Aug;35(8):680-9. PubmedPMID: 12196221.

[14]. Janani K, Palanivelu A, Sandhya R. Diagnostic accuracy of dental pulse oximeter with customized sensor holder, thermal test and electric pulp test for the evaluation of pulp vitality: an in vivo study. Brazilian Dental Science. 2020 Jan 31;23(1):8-p.

[15]. Jose J, Subbaiyan H. Different treatment modalities followed by dental practitioners for ellis class 2 fracture-A questionnaire-based survey. The Open Dentistry Journal. 2020 Feb 18;14(1).

[16]. Kumar D, Antony SD. Calcified canal and negotiation-A review. Research Journal of Pharmacy and Technology. 2018 Aug 1;11(8):3727-30.
[17]. Lupi-Pegurier L, Bertrand MF, Muller-Bolla M, Rocca JP, Bolla M. Periapical status, prevalence and quality of endodontic treatment in an adult French population. IntEndod J. 2002 Aug;35(8):690-7. PubmedPMID: 12196222.

[18]. Manohar MP, Sharma S. A survey of the knowledge, attitude, and awareness about the principal choice of intracanal medicaments among the general dental practitioners and nonendodontic specialists. Indian J Dent Res. 2018 Nov-Dec;29(6):716-720. PubmedPMID: 30588997.

[19]. Metzger Z, Abramovitz R, Abramovitz L, Tagger M. Correlation between remaining length of root canal fillings after immediate post space preparation and coronal leakage. J Endod. 2000 Dec;26(12):724-8. PubmedPMID: 11471642.

[20]. Nandakumar M, Nasim I. Comparative evaluation of grape seed and cranberry extracts in preventing enamel erosion: An optical emission spectrometric analysis. J Conserv Dent. 2018 Sep-Oct;21(5):516-520. PubmedPMID: 30294113.

[21]. Hussainy SN, Nasim I, Thomas T, Ranjan M. Clinical performance of resinmodified glass ionomer cement, flowable composite, and polyacid-modified resin composite in noncarious cervical lesions: One-year follow-up. J Conserv Dent. 2018 Sep-Oct;21(5):510-515. PubmedPMID: 30294112.

[22]. Noor SS. Chlorhexidine: Its properties and effects. Research Journal of Pharmacy and Technology. 2016 Oct 1;9(10):1755.

[23]. ØRstavik DA. Materials used for root canal obturation: technical, biological and clinical testing. Endodontic topics. 2005 Nov;12(1):25-38.

[24]. Rajakeerthi R, Nivedhitha MS. Natural Product as the Storage medium for an avulsed tooth-A Systematic Review. Cumhuriyet Dental Journal. 2019;22(2):249-56

[25]. Rajendran R, Kunjusankaran RN, Sandhya R, Anilkumar A, Santhosh R, Patil SR. Comparative evaluation of remineralizing potential of a paste containing bioactive glass and a topical cream containing casein phosphopeptide-amorphous calcium phosphate: An in vitro study. Pesquisabrasileiraemodontopediatria e clinicaintegrada. 2019;19.

[26]. Ramamoorthi S, Nivedhitha MS, Divyanand MJ. Comparative evaluation of postoperative pain after using endodontic needle and EndoActivator during root canal irrigation: A randomised controlled trial. AustEndod J. 2015 Aug;41(2):78-87. PubmedPMID: 25195661.

[27]. Ramanathan S, Solete P. Cone-beam Computed Tomography Evaluation of Root Canal Preparation using Various Rotary Instruments: An in vitro Study. J Contemp Dent Pract. 2015 Nov 1;16(11):869-72.PubmedPMID: 26718293.

[28]. Ravinthar K. Recent advancements in laminates and veneers in dentistry. Research Journal of Pharmacy and Technology. 2018 Feb 1;11(2):785-7.

[29]. Ray HA, Trope M. Periapical status of endodontically treated teeth in relation to the technical quality of the root filling and the coronal restoration. IntEndod J. 1995 Jan;28(1):12-8. PubmedPMID: 7642323.

[30]. Ricketts DN, Tait CM, Higgins AJ. Tooth preparation for post-retained restorations. Br Dent J. 2005 Apr 23;198(8):463-71. PubmedPMID: 15849574.

[31]. Siddique R, Sureshbabu NM, Somasundaram J, Jacob B, Selvam D. Qualitative and quantitative analysis of precipitate formation following interaction of chlorhexidine with sodium hypochlorite, neem, and tulsi. J Conserv Dent. 2019 Jan-Feb;22(1):40-47. PubmedPMID: 30820081.

[32]. Siqueira JF Jr, Rôças IN, Alves FR, Campos LC. Periradicular status related to the quality of coronal restorations and root canal fillings in a Brazilian population. Oral Surg Oral Med Oral Pathol Oral RadiolEndod. 2005 Sep;100(3):369-74. PubmedPMID: 16122668.

[33]. Sjogren U, Hagglund B, Sundqvist G, Wing K. Factors affecting the longterm results of endodontic treatment. J Endod. 1990 Oct;16(10):498-504. PubmedPMID: 2084204.

[34]. Strindberg LZ. The dependence of the results of pulp therapy on certain factors-an analytical study based on radiographic and clinical follow-up examination. ActaOdontol Scand. 1956;14:1-75.

[35]. Swanson K, Madison S. An evaluation of coronal microleakage in endodontically treated teeth. Part I. Time periods. J Endod. 1987 Feb;13(2):56-9. PubmedPMID: 3470424.

[36]. Teja KV, Ramesh S. Shape optimal and clean more. Saudi Endodontic Journal. 2019 Sep 1;9(3):235.

[37]. Teja KV, Ramesh S, Priya V. Regulation of matrix metalloproteinase-3 gene expression in inflammation: A molecular study. J Conserv Dent. 2018 NovDec;21(6):592-596. PubmedPMID: 30546201.

[38]. Torabinejad M, Ung B, Kettering JD. In vitro bacterial penetration of coronally unsealed endodontically treated teeth. J Endod. 1990 Dec;16(12):5669. PubmedPMID: 2094758

[39]. Whitworth J. Methods of filling root canals: principles and practices. Endodontic topics. 2005 Nov;12(1):2-4. 